\title{
PARACOCCIDIOIDOMYCOSIS: CHALLENGES IN THE DEVELOPMENT OF A VACCINE AGAINST AN ENDEMIC MYCOSIS IN THE AMERICAS
}

Carlos. P. TABORDA(1,2), M.E. URÁN(2), J. D. NOSANCHUK(3) \& L.R. TRAVASSOS(4)

\begin{abstract}
SUMMARY
Paracoccidioidomycosis (PCM), caused by Paracoccidioides spp, is an important endemic mycosis in Latin America. There are two recognized Paracoccidioides species, $P$. brasiliensis and $P$. lutzii, based on phylogenetic differences; however, the pathogenesis and disease manifestations of both are indistinguishable at present. Approximately 1,853 ( 51,2\%) of 3,583 confirmed deaths in Brazil due to systemic mycoses from 1996-2006 were caused by PCM. Antifungal treatment is required for patients with PCM. The initial treatment lasts from two to six months and sulfa derivatives, amphotericin B, azoles and terbinafine are used in clinical practice; however, despite prolonged therapy, relapses are still a problem. An effective Th1-biased cellular immune response is essential to control the disease, which can be induced by exogenous antigens or modulated by prophylactic or therapeutic vaccines. Stimulation of B cells or passive transference of monoclonal antibodies are also important means that may be used to improve the efficacy of paracoccidioidomycosis treatment in the future. This review critically details major challenges facing the development of a vaccine to combat PCM.
\end{abstract}

KEYWORDS: Paracoccidioides brasiliensis; Paracoccidioides lutzii; Peptide P10; Vaccine; Immunoprotection.

\section{REVIEW}

Paracoccidioidomycosis (PCM), is a systemic mycosis with clinical manifestations of a granulomatous disease, caused by thermally dimorphic Paracoccidioides spp. Adolpho Lutz first described this fungus in 1908, while examining oral lesions in two patients ${ }^{16}$. PCM is the most frequent systemic endemic mycosis in Latin America, with the highest incidence of diagnosis in Brazil, Argentina, Colombia, and Venezuela ${ }^{23}$. The main route of infection is the inhalation of fungal particles, which usually leads to an asymptomatic infection ${ }^{4}$. There are two main clinical forms of PCM, acute/subacute and chronic. The acute/subacute form is characterized by a rapid disease course (weeks to months), impaired cellular immunity, an absence of delayed-type hypersensitivity reactions and a high mortality rate. The chronic form affects mainly $30-50$ years old males with disease manifestations that are predominant pulmonary and/ or mucocutaneous ${ }^{13}$. In terms of mortality, based on data obtained from the Brazilian Ministry of Health's Mortality Information, approximately $1,853(\sim 51,2 \%)$ of 3,583 confirmed deaths in Brazil due to systemic mycoses from 1996-2006 were caused by $\mathrm{PCM}^{22}$.

Expanding on the description of $P$. brasiliensis by Adolpho Lutz, modern molecular studies analyzing the genetic variability of strains revealed the existence of three distinct phylogenetic groups, namely: S1 - paraphyletic group with isolates from Argentina, Brazil, Peru and
Venezuela; PS2 - monophyletic group with isolates from Brazil and Venezuela; and PS3 - monophyletic group with Colombian isolates only ${ }^{30}$. Subsequently, a complementary comparative genomic study identified an isolate that was separated from the other groups distributed on the Paracoccidioides cladogram ${ }^{8}$. This analysis led to a re-classification of this isolate as a new species within the genus, named Paracoccidioides lutzii ${ }^{29}$, which is now known to be endemic in the North and CentralWest regions of Brazil (States of Rondonia, Mato Grosso and Goias) and geographically partially overlaps with group S1. Despite the genetic differences, the pathogenesis and disease manifestations of $P$. brasiliensis and $P$. lutzii are indistinguishable at present. One important difference, is that $P$. lutzii does not properly express a key glycoprotein, gp $43^{30}$, which is a target of vaccine development detailed below.

Antifungal chemotherapy is required for clinical PCM, although there is no certainty of total elimination of the fungus at the end of treatment. Initial treatment lasts from two to six months based on the extent of disease and clinical response to therapy, and typically includes the use of sulfa derivatives (sulfadiazine, sulfadoxine, sulfamethoxypyridazine, cotrimazine and trimethoprim-sulfamethoxazole) although amphotericin $\mathrm{B}$, azoles (ketoconazole, itraconazole, fluconazole, voriconazole and posaconazole) or terbinafine may also be used. After the initial intensive therapy, extended periods of treatment are often necessary, up to two or more years, with a significant frequency of relapsing disease ${ }^{3,26}$.

(1) Universidade de São Paulo, Instituto de Ciências Biomédicas, Departamento de Microbiologia, São Paulo, SP, Brasil.

(2) Universidade de São Paulo, Instituto de Medicina Tropical, Laboratório de Micologia Médica LIM53/HCFMUSP, São Paulo, SP, Brasil.

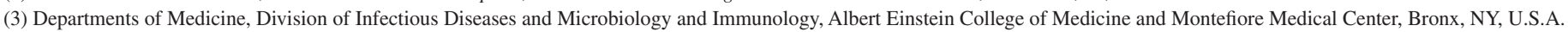

(4) Universidade Federal de São Paulo, Departmento de Microbiologia, Imunologia e Parasitologia, São Paulo, SP, Brasil.

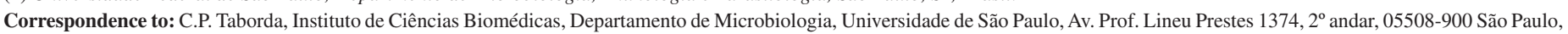
SP, Brasil. Tel: +55.11.3091-7345, FAX : +55.11.3091-7354. E-mail: taborda@usp.br 


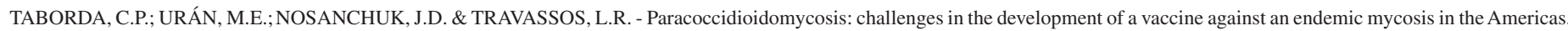
Rev. Inst. Med. Trop. Sao Paulo, 57(Suppl 19): 21-4, 2015.

Protection against PCM has been attributed to the induction of cellular immune responses whereas high levels of specific antibodies have been associated with the symptomatic form of the disease. A major line of investigation has focused on purified antigens in the attempt to develop a peptide vaccine. The glycoprotein gp43 is the main antigen target of P. brasiliensis and a 15-mer internal peptide (QTLIAIHTLAIRYAN), known as $\mathrm{P} 10$, contains the major $\mathrm{CD}^{+}{ }^{+}$specific $\mathrm{T}$ cell epitope and elicits an IFN- $\gamma$-dependent Th1 immune response. Immunization with P10 of intratracheally infected BALB/c mice, in the presence of complete Freund adjuvant (CFA) reduces the fungal burden in the lungs, liver and spleen ${ }^{28,32}$.

The protection by $\mathrm{P} 10$ administered in $\mathrm{CFA}^{18}$ observed in a prophylactic protocol was also obtained therapeutically in P. brasiliensisinfected immunocompetent mice. Similar results were observed in partially immunosuppressed mice ${ }^{21}$, in which case fibrosis was also precluded.

Complete Freund adjuvant causes a variety of side effects such as localized injection-site granulomas, hepatic and renal granuloma formation and necrotizing dermatitis. Hence, the use of this adjuvant has been banned in humans as well as in non-experimental veterinary administration ${ }^{27}$. With this in mind, our group tested the therapeutic effects of P10 combined with different adjuvants (aluminum hydroxide, CFA, flagellin and the cationic lipid dioctadecyl-dimethylammonium bromide (DODAB)) in BALB/c mice previously infected with P. brasiliensis $^{19}$. Seventy days after infection, mice treated with DODAB and P10, and with less intensity, mice treated with P10 and flagellin, showed the most prominent effects. Concomitantly, secretion of IFN- $\gamma$ and TNF- $\alpha$, in contrast to IL-4 and IL-10, was enhanced in the lungs of mice immunized with P10 in combination with the tested adjuvants, with the best results observed in mice treated with P10 and DODAB ${ }^{19}$.

The incorportion of P10 in Poly (lactic acid-glycolic acid) nanoparticles (PLGA) at $1 \mu \mathrm{g} / 50 \mu \mathrm{L}$ with TMP/SMZ was also tested. It reduced the amount of peptide necessary to decrease the fungal load in the infected animals and avoid disease relapse when compared with P10 emulsified in Freund's adjuvant $(20 \mu \mathrm{g} / 50 \mu \mathrm{L})^{2}$.

The use of pcDNA3 expression vector encoding P10 was a gene therapy approach tested in intratracheally infected mice. The plasmid vaccine induced a significant reduction of fungal burden in the lung. Covaccination with a plasmid encoding mouse IL-12 proved to be even more effective in the elimination of the fungus with virtual sterilization in a long term (five months) infection and treatment assay ${ }^{25}$. The immunization with plasmid encoding P10 was also able to induce memory cells ${ }^{6}$.

Dendritic cells (DCs) pulsed with P10 protected mice infected with $P$. brasiliensis. The adoptive transference of pulsed dendritic cells in mice previously infected with the fungus reduced the fungal burden in their lungs ${ }^{17}$. FERREIRA et al., $(2011)^{12}$ used DCs transfected with plasmid (pMAC/PS-scFv) encoding a single chain variable fragment $(\mathrm{scFv})$ of an anti-Id antibody that was capable of mimicking gp43. Mice immunized subcutaneously with pMAC/PS-scFv decreased the lung infection.

Other peptides from $43 \mathrm{kDa}$ glycoprotein showed different properties such as P4 and P23 that inhibit macrophage functions and the inflammatory reaction, thus facilitating infection ${ }^{14,15}$. P4 and P23 were evaluated in different models in vivo, and suggested that this anti-inflammatory effect depended on the kinetics of innate immunity modulators such as TNF- $\alpha$, IL6, IL10 and TLR2. IL10 seems to be produced earlier than TNF- $\alpha$ and IL6, in presence of the peptides. The anti-inflammatory effects of P4 and P23 depended on the amount and frequency of treatment ${ }^{15}$.

Besides the use of gp43 and P10 as vaccines, other antigens have been investigated as additional vaccine options against $P$. brasiliensis. cDNA encoding the $27 \mathrm{kDa}$ protein present at the surface and cytosol of $P$. brasiliensis was subcloned into a pET-DEST 42 plasmid and expressed in Escherichia coli ( $\mathrm{rPb} 27)$. BALB/c mice were infected with virulent $P$. brasiliensis and after being immunized subcutaneously with purified $\mathrm{rPb} 27$ in the presence of Corynebacterium parvum and aluminum hydroxide, some mice were also treated with fluconazol. After 40 days of treatment, the combined administration of plasmid and chemotherapeutics controlled PCM in the lung, liver and spleen ${ }^{10,11}$. A therapeutic study was conducted to evaluate fibrosis development in animals immunized with $\mathrm{rPb} 27$ and infected. After 30 and 90 days postinfection reduced levels of collagen and receptor CCR7 were observed with high levels of active caspase 3 , IFN- $\gamma$, TGF- $\beta$ and IL- 10 on the early phase of infection. In the control groups that developed high levels of pulmonary fibrosis, the molecule could be promising as a prophylactic and therapeutic treatment against $\mathrm{PCM}^{20}$. The use of $\mathrm{rPb} 40$ together with $\mathrm{rPb} 27$, combined with conventional treatment, exhibited additive protective effect ${ }^{10}$.

Recombinant paracoccin (the sequence matched a hypothetical protein encoded by PADG-3347 of $P$. brasiliensis 18 , with a polypeptide sequence similar to endochitinase) expressed in E. coli cells showed protective effect in infected mice reducing the fungal burden ${ }^{1}$. Otherwise, radioattenuated yeast cells of $P$. brasiliensis reduced the fungal burden in infected mice 9 . DNAhsp65 (Heat shock protein from Mycobacterium leprae) administered by intramuscular immunization in BALB/c mice promoted an increase in Th-1 cytokines and reduced the fungal burden ${ }^{24}$.

The role of antibody-mediated immunity in PCM has been less certain as in early studies it was believed that antibodies were useful only for serological diagnosis. More recently, monoclonal antibodies (mAbs) have been shown to significantly modify PCM. The first demonstration of this utilized mAbs against gp70 of $P$. brasiliensis $^{7}$. In fact, both protective and non-protective $\mathrm{mAb}$ have been identified as exemplified by a panel of mAbs recognizing gp43, of which $\mathrm{mAb} 3 \mathrm{E}$ was the most efficient in reducing the fungal burden in vivo and promoting fungal phagocytosis in vitro ${ }^{5}$. MAb 3E recognized the epitope sequence NHVRIPIGYWAV. Significantly, combining P10 preimmunization with the administered of $\mathrm{mAb} 3 \mathrm{E} 24 \mathrm{~h}$ before intratracheal challenge with virulent $P$. brasiliensis yeasts resulted in additive protection using a short-term protocol in comparison with a non-protective $\mathrm{mAb}^{32}$.

The mechanisms for protection against $P$. lutzii are not well elucidated. We recently demonstrated that mAbs generated against the heat shock protein 60 (Hsp60) from Histoplasma capsulatum interacted with $P$. lutzii yeast cells and enhanced phagocytosis by macrophages cells ${ }^{31}$. The passive transfer of Hsp60-binding mAbs 7B6 and 4E12 significantly reduced the lung fungal burden in BALB/c mice intratracheally infected with P. lutzii. 
TABORDA, C.P.; URÁN, M.E.; NOSANCHUK, J.D. \& TRAVASSOS, L.R. - Paracoccidioidomycosis: challenges in the development of a vaccine against an endemic mycosis in the Americas. Rev. Inst. Med. Trop. Sao Paulo, 57(Suppl 19): 21-4, 2015.

Although we currently have several therapeutic options for the treatment of PCM, these regimens require protracted administration of antifungal drugs, increasing both the costs of therapy and the incidence of toxicities. Moreover, there are frequent relapses despite more than one or two years to antifungal treatment. In light of this, efforts are underway to harness the host immune system to generate protective responses that can improve the efficacy and reduce the duration of treatment. The use of peptides, purified antigens, DNA therapy, peptide-pulsed DCs, radio attenuated yeast cells, monoclonal antibodies, etc. are being explored as potential components of a therapeutic vaccine. To date, these promising studies have provided results in experimental model or in vitro in patients' cells. We are now poised to transition the large amount of knowledge gained through these studies into clinical trials aimed at improving our ability to combat PCM.

\section{RESUMO}

\section{Paracoccidioidomicose: desafios no desenvolvimento de uma vacina contra micose endêmica nas Américas}

A paracoccidioidomicose (PCM), causada por Paracoccidioides spp, é importante micose endêmica na América Latina. Com base em diferenças filogenéticas, existem duas espécies reconhecidas de Paracoccidioides, $P$. brasiliensis e $P$. lutzii, no entanto, a patogênese e as manifestações clínicas de ambas são indistinguíveis atualmente. Aproximadamente 1853 ( 51,2\%) de 3583 mortes confirmadas, atribuídas a micoses sistêmicas de 1996-2006, no Brasil foram causadas por PCM. Tratamento antifúngico é necessário para pacientes com PCM. $\mathrm{O}$ tratamento inicial dura de dois a seis meses e derivados de sulfa, anfotericina $\mathrm{B}$, azóis e terbinafina são utilizados na prática clínica; no entanto, apesar da terapêutica prolongada, as recaídas ainda são um problema. Uma resposta imune celular eficaz, tendendo a Th1, é essencial para controlar a doença que pode ser induzida por antígenos exógenos, ou moduladas por vacinas profiláticas ou terapêuticas. A estimulação de células B ou a transferência passiva de anticorpos monoclonais também são meios importantes que podem ser utilizados para melhorar a eficácia do tratamento da paracoccidioidomicose no futuro. Esta revisão detalha criticamente os principais desafios que o desenvolvimento de uma vacina para combater a PCM enfrenta.

\section{ACKNOWLEDGMENTS}

The authors thank Fundação de Amparo à Pesquisa do Estado de São Paulo (Fapesp) for research grants, the National Research Council $(\mathrm{CNPq})$ for career fellowships and the Coordenação de Aperfeiçoamento de Pessoal de Nivel Superior (CAPES) for PEC-PG fellowship.

\section{REFERENCES}

1. Alegre AC, Oliveira AF, Dos Reis Almeida FB, Roque-Barreira MC, Hanna ES Recombinant paracoccin reproduces the biological properties of the native protein and induces protective Th1 immunity against Paracoccidioides brasiliensis infection. PLOS Negl Trop Dis. 2014;8:e2788.

2. Amaral AC, Marques AF, Munoz JE, Bocca AL, Simioni AR, Tedesco AC, et al. Poly(lactic acid-glycolic acid) nanoparticles markedly improve immunologica protection provided by peptide P10 against murine paracoccidioidomycosis. Br J Pharmacol. 2010;159:1126-32.
3. Bocca AL, Amaral AC, Teixeira MM, Sato PK, Shikanai-Yasuda MA, Soares Felipe MS. Paracoccidioidomycosis: eco-epidemiology, taxonomy and clinical and therapeutic issues. Future Microbiol. 2013;8:1177-91.

4. Brummer E, Castaneda E, Restrepo A. Paracoccidioidomycosis: an update. Clin Microbiol Rev. 1993;6:89-117.

5. Buissa-Filho R, Puccia R, Marques AF, Pinto FA, Munoz JE, Nosanchuk JD, et al. The monoclonal antibody against the major diagnostic antigen of Paracoccidioides brasiliensis mediates immune protection in infected BALB/c mice challenged intratracheally with the fungus. Infect Immun. 2008;76:3321-8.

6. de Amorim J, Magalhaes A, Muñoz JE, Rittner GM, Nosanchuk JD, Travassos LR, et al. DNA vaccine encoding peptide $\mathrm{P} 10$ against experimental paracoccidioidomycosis induces long-term protection in presence of regulatory $\mathrm{T}$ cells. Microbes Infect. 2013;15:181-91

7. de Mattos Grosso D, de Almeida SR, Mariano M, Lopes JD. Characterization of gp70 and anti-gp70 monoclonal antibodies in Paracoccidioides brasiliensis pathogenesis. Infect Immun. 2003;71:6534-42.

8. Desjardins CA, Champion MD, Holder JW, Muszewska A, Goldberg J, Bailao $\mathrm{AM}$, et al. Comparative genomic analysis of human fungal pathogens causing paracoccidioidomycosis. PLOS Genet. 2011;7:e1002345.

9. do Nascimento Martins EM, Reis BS, de Resende MA, de Andrade AS, Goes AM. Mice immunization with radioattenuated yeast cells of Paracoccidioides brasiliensis: influence of the number of immunizations. Mycopathologia. 2009;168:51-8.

10. Fernandes VC, Coitinho JB, Veloso JM, Araujo SA, Pedroso EP, Goes AM Combined use of Paracoccidioides brasiliensis recombinant $\mathrm{rPb} 27$ and $\mathrm{rPb} 40$ antigens in an enzyme-linked immunosorbent assay for immunodiagnosis of paracoccidioidomycosis. J Immunol Methods. 2011;367(1-2):78-84.

11. Fernandes VC, Martins EM, Boeloni JN, Coitinho JB, Serakides R, Goes AM. Additive effect of $\mathrm{rPb} 27$ immunization and chemotherapy in experimental paracoccidioidomycosis. PLOS ONE. 2011;6:e17885.

12. Ferreira KS, Maranhão AQ, Garcia MC, Brigido MM, Santos SS, Lopes JD, et al Dendritic cells transfected with scFv from Mab 7.B12 mimicking original antigen gp43 induces protection against experimental paracoccidioidomycosis. PLOS ONE. 2011;6:e15935.

13. Franco M. Host-parasite relationships in paracoccidioidomycosis. J Med Vet Mycol. $1987 ; 25: 5-18$

14. Konno AY, Maricato JT, Konno FT, Mariano M, Lopes JD. Peptides from Paracoccidioides brasiliensis GP43 inhibit macrophage functions and inflammatory response. Microbes Infect. 2009;11:92-9.

15. Konno FT, Maricato J, Konno AY, Guereschi MG, Vivanco BC, Feitosa L dos S, et al. Paracoccidioides brasiliensis GP43-derived peptides are potent modulators of local and systemic inflammatory response. Microbes Infect. 2012;14:517-27.

16. Lacaz CS. Evolução dos conhecimentos sobre a paracoccidioidomicose. Um pouco da história. In: Del Negro G, Lacaz CS, Fiorillo AM, editores. Paracoccidioidomicose blastomicose sul-americana. São Paulo: Sarvier; 1982. p. 1-9.

17. Magalhães A, Ferreira KS, Almeida SR, Nosanchuk JD, Travassos LR, Taborda CP Prophylactic and therapeutic vaccination using dendritic cells primed with peptide 10 derived from the 43-kilodalton glycoprotein of Paracoccidioides brasiliensis. Clin Vaccine Immunol. 2012;19:23-9.

18. Marques AF, da Silva MB, Juliano MA, Munhoz JE, Travassos LR, Taborda CP. Additive effect of P10 immunization and chemotherapy in anergic mice challenged intratracheally with virulent yeasts of Paracoccidioides brasiliensis. Microbes Infect. 2008;10(12-13):1251-8. 
TABORDA, C.P.; URÁN, M.E.; NOSANCHUK, J.D. \& TRAVASSOS, L.R. - Paracoccidioidomycosis: challenges in the development of a vaccine against an endemic mycosis in the Americas Rev. Inst. Med. Trop. Sao Paulo, 57(Suppl 19): 21-4, 2015.

19. Mayorga O, Muñoz JE, Lincopan N, Teixeira AF, Ferreira LC, Travassos LR, et al. The role of adjuvants in therapeutic protection against paracoccidioidomycosis after immunization with the P10 peptide. Front Microbiol. 2012;3:154.

20. Morais EA, Martins EM, Boelone JN, Gomes DA, Goes AM. Immunization with recombinant $\mathrm{Pb} 27$ protein reduces the levels of pulmonary fibrosis caused by the inflammatory response against Paracoccidioides brasiliensis. Mycopathologia. 2015;179(1-2):31-43

21. Munoz JE, Luft VD, Amorim J, Magalhaes A, Thomaz L, Nosanchuk JD, et al. Immunization with $\mathrm{P} 10$ peptide increases specific immunity and protects immunosuppressed BALB/c mice infected with virulent yeasts of Paracoccidioides brasiliensis. Mycopathologia. 2014;178(3-4):177-88.

22. Prado M, Silva MB, Laurenti R, Travassos LR, Taborda CP. Mortality due to systemic mycoses as a primary cause of death or in association with AIDS in Brazil: a review from 1996 to 2006. Mem Inst Oswaldo Cruz. 2009;104:513-21.

23. Restrepo A, McEwen JG, Castañeda E. The habitat of Paracoccidioides brasiliensis: how far from solving the riddle? Med Mycol. 2001;39:233-41.

24. Ribeiro AM, Bocca AL, Amaral AC, Faccioli LH, Galetti FC, Zárate-Bladés CR, et al. DNAhsp65 vaccination induces protection in mice against Paracoccidioides brasiliensis infection. Vaccine. 2009;27:606-13.

25. Rittner GM, Muñoz JE, Marques AF, Nosanchuk JD, Taborda CP, Travassos LR. Therapeutic DNA vaccine encoding peptide P10 against experimental paracoccidioidomycosis. PLOS Negl Trop Dis. 2012;6:e1519.
26. Shikanai-Yasuda MA, Telles Filho F de Q, Mendes RP, Colombo AL, Moretti ML. Consenso em paracoccidioidomicose. Rev Soc Bras Med Trop. 2006;39:297-310.

27. Stills HF Jr. Adjuvants and antibody production: dispelling the myths associated with Freund's complete and other adjuvants. ILAR J. 2005;46:280-93.

28. Taborda CP, Juliano MA, Puccia R, Franco M, Travassos LR. Mapping of the T-cell epitope in the major 43-kilodalton glycoprotein of Paracoccidioides brasiliensis which induces a Th-1 response protective against fungal infection in BALB/c mice. Infect Immun. 1998;66:786-93.

29. Teixeira M de M, Theodoro RC, Derengowski L da S, Nicola AM, Bagagli E, Felipe MS. Molecular and morphological data support the existence of a sexual cycle in species of the genus Paracoccidioides. Eukaryot Cell. 2013;12:380-9.

30. Teixeira MM, Theodoro RC, de Carvalho MJ, Fernandes L, Paes HC, Hahn RC, et al. Phylogenetic analysis reveals a high level of speciation in the Paracoccidioides genus. Mol Phylogenet Evol. 2009;52:273-83.

31. Thomaz L, Nosanchuk JD, Rossi DC, Travassos LR, Taborda CP. Monoclonal antibodies to heat shock protein 60 induce a protective immune response against experimental Paracoccidioides lutzii. Microbes Infect. 2014;16:788-95.

32. Travassos LR, Taborda CP. New advances in the development of a vaccine against paracoccidioidomycosis. Front Microbiol. 2012;3:212. 